\title{
Estimasi Kecepatan Gelombang Geser (Vs) Berdasarkan Inversi Mikrotremor Spectrum Horizontal to Vertikal Spectral Ratio (HVSR) Studi Kasus : Tanah Longsor Desa Olak-Alen, Blitar
}

\author{
Imam Gazali, M. Singgih Purwanto, Dwa Desa Warnana \\ Departemen Teknik Geofisika, FTSP, Institut Teknologi Sepuluh Nopember (ITS) \\ e-mail:dwa_desa@geofisika.its.ac.id
}

\begin{abstract}
Abstrak-Bencana gerakan tanah merupakan bencana yang sering terjadi di kabupaten Blitar. Salah satu daerah yang sering terkena dampak peristiwa tersebut adalah desa Olak-Alen, yang ditandai dengan adanya longsor. Hal ini dikarenakan pada daerah tersebut terletak pada kondisi geologi yang tersusun tuff dan pasiran yang mempunyai potensi lebih besar terhadap efek intensitas gerakan tanah. Pada penelitian ini parameter fisis yang digunakan untuk mikrozonasi yaitu kurva HVSR dan sebaran Vs hasil inversi kurva HVSR. Berdasarkan hasil penelitian didapatkan nilai frekuensi natural antara 1.7-3.7 Hz, Puncak HVSR antara 2-9 dan Indeks Kerentanan antara 1.5-44.7. daerah yang diduga sebagai bidang gelincir memiliki nilai kecepatan geser 200-300 m/s yang diklasifikasikan sebagai tanah tipe D berdasarkan SNI 1726-2012 dan tipe C menurut Eurocode 8. Sedangkan bedrock pada penelitian ini memiliki nilai kecepatan geser 750-1200 m/s yang tersebar pada kedalaman 50-60 meter.
\end{abstract}

Kata Kunci-Desa Olak-Alen, Longsor, HVSR, Kecepatan Gelombang Geser (Vs).

\section{PENDAHULUAN}

$\mathrm{B}^{\mathrm{s}}$ ENCANA gerakan tanah merupakan bencana yang sering terjadi di kabupaten Blitar. Berdasarkan laporan Pusat Vulkanologi dan Mitigasi Bencana Geologi tahun 2016 diketahui bahwa kabupaten Blitar mempunyai potensi gerakan tanah pada zona menengah-tinggi. Hal ini menunjukkan bahwa pada zona ini dapat terjadi gerakan tanah jika curah hujan diatas normal. Desa Olak Alen merupakan salah satu desa di kabupaten Blitar yang setiap tahunnya terkena dampak dari pereistiwa tersebut. Peristiwa gerakan tanah terakhir terjadi pada hari jumat tanggal 2 Desember 2016. Akibatnya 2 rumah hancur, 7 rumah dalam area berbahaya dan 2 titik jalan terputus, yaitu di jalan desa Olak Alen dan di jalur bawah jalan Blitar-Malang [1]. Secara umum topografi di sekitar gerakan tanah berupa perbukitan bergelombang dengan ketinggian lebih dari 390 mdpl. Berdasarkan peta geologi teknik lembar kabupaten Blitar, desa Olak Alen merupakan daerah yang hamper seluruh bagiannya terbentuk oleh endapan gunung api Butak yang terdiri atas lava, breksi gunung api, tuf breksi dan tuf pasiran dan sisanya berupa endapan tuf [2]. Selain itu menurut Nakamura kondisi geologi seperti endapan alluvial, tuff dan batu pasir mempunyai potensi bahaya yang lebih besar terhadap efek intensitas gerakan tanah terhadap gangguan karena gempa bumi [3]. Oleh karena itu, pengetahuan kondisi tanah secara lokal menjadi bagia yang sangat penting dalam memerkirakan bahaya gerakan tanah secara spesifik. Salah satu parameter penting yang harus diketahui adalah deleniasi kecepatan gelombang geser (Vs) pada lapisan bawah permukaan tanah yang dapat menjadi pengontrol faktor amplifikasi dari gelombang seismik selama gempa bumi. Dengan diketahuinya parameter tersebut dapat digunakan untuk mengklasifikasi dan mengkarakterisasi tanah penyebab terjadinya gerakan tanah pada desa Olak Alen. Kemudian dari parameter tersebut dapat ditentukan area rawan pada lokasi penelitian.

Selain itu berdasarkan Sutrisno (2014) Vs juga digunakan sebagai nilai referensi awal dalam masalah strain terhadap pembebanan seismik [4]. Di indonesia, umumnya Vs diukur dengan menggunakan uji downhole. Namun peralatan ini tidak tersedia secara luas, akibatnya uji menjadi terlalu mahal dalam melakukan sebagian proyek kontruksi. Di sisi lain, uji laboratorium dari hasil boring dapat dieksplorasi lebih lanjut untuk mendapatkan nilai Vs. Gardner dan Gregory (1974) melakukan serangkaian studi empiris untuk menentukan hubungan keterikatan antara Vp, Vs dan densitas [5].

$$
\rho=a V_{p}^{\frac{1}{4}}
$$

Dengan $\rho$ dalam $\mathrm{g} / \mathrm{cm}^{3}, \alpha$ adalah koefisien dengan nilai 0.31 ketika $\mathrm{V}$ dalam $\mathrm{m} / \mathrm{s}$ dan digunakan 0.23 ketika $\mathrm{V}$ dalam $\mathrm{ft} / \mathrm{s}$. Setalah parameter Vp didapatkan, maka parameter Vs dapat ditentukan.

Selanjutnya nilai kecepatan geser (Vs) hasil uji downhole digunakan sebagai parameter model untuk mendapatkan sebaran kecepatan geser dari proses inversi kurva HVSR hasil observasi mikrotemor dilapangan. Analisis mikrotremor 
dengan menggunakan metode HVSR (Horizontal to Vetical Spectrum Ratio) merupakan salah satu cara yang paling mudah dan paling murah untuk memahami sifat struktur lapisan bawah permukaan tanpa menyebabkan gangguan pada struktur tersebut.

\section{METODOLOGI PENELITIAN}

\section{A. Pengukuran Data Lapangan}

Pengambilan data eksperimen metode mikrotremor HVSR dilakukan di dusun Sumberejo desa Olak Alen, Blitar. Desain pengukuran dilakukan dengan memotong area gerakan tanah dan membentuk grid dengan luasan 400 x 200 meter. Dilakukan dengan desain seperti itu agar didapatkan perbandingan respon hasil pengukuran mikrotremor di daerah yang telah terjadi gerakan tanah terhadap daerah sekitarnya dan untuk melihat arah kemenerusan gerakan tanah yang mungkin akan terjadi. Proses pengambilan data dilakukan dengan meletakkan seismometer Sara SL-07 mengarah ke Utara dengan posisi bull eye tepat ditengah. Untuk menghindari gangguan noise seismometer di tutup dengan payung dan menghindari pengukuran yang dekat dengan pepohonan sehingga proses perekaman noise dari permukaan tanah lebih baik. Lama perakaman yang dilakukan adalah 1800 detik dengan frekuensi sampling $100 \mathrm{~Hz}$. Perekaman dilakukan dengan menggunakan software HyperTerminal dengan format data yang dihasilkan adalah berbentuk EV0, EV1 dan EV2.

\section{B. Tahap Pengolahan Data HVSR}

Pengolahan ini dilakukan untuk mendapatkan rasio spectrum horizontal terhadap vertikal (H/V) dari semua jenis sinyal getaran (ambient noise gempa bumi, cuaca, maupun aktifitas manusia). Untuk pemprosesan $\mathrm{H} / \mathrm{V}$, data yang digunakan harus memiliki 3 komponen sinyal yaitu NorthSouth, East-West dan vertical, serta sampel yang cukup (dalam waktu) untuk bisa diolah. Sebelumnya dilakukan proses FFT (Fast Fourier Transform) dan smoothing kemudian dilakukan penggabungan komponen horizontal dan vertikal kedalam analisis HVSR berupa spectral rasio amplitude spektrum Fourier dari persamaan berikut :

$$
R(t)=\left[\frac{\sqrt{F N S(T)^{2}+F E W(T)^{2}}}{F Z(T)}\right]
$$

Dengan $R(T)$ adalah spektrum rasio vertikal terhadap horizontal, $F_{N S}$ adalah spektrum fourier di NS dan $F_{E W}$ adalah spektrum fourier di $\mathrm{EW}$ serta $\mathrm{F}_{\mathrm{Z}}$ adalah spektrum fourier di $\mathrm{Z}$ (vertikal). Selanjutnya rata-rata spektrum HVSR diplot untuk setiap titik pengukuran setelah diperoleh sepektrum HVSR masing-masing window.

\section{Tahap Inversi dengan OpenHVSR}

OpenHVSR merupakan software untuk menghasilkan model struktur bawah permukaan dari kurva HVSR dengan menggunakan metode propagasi Monte Carlo. Software ini dituliskan dalam software Matlab basis GUI. Dalam penggunaan OpenHVSR dalam proses inversi ada beberapa data yang harus dipersiapkan.

Berikut langkah pengolahan inversi dengan OpenHVSR :

1.Perhitungan data konstrain :

- Analisis densitas dari data sekunder (soil boring),

- Perhitungan nilai Vp, Vs, Qp, dan Qs dari data densitas dengan persamaan 1.

2. Proses Inversi OpenHVSR

Sebelum melakukan inversi kita harus menyiapkan data subsurface hasil perhitungan parameter model yang didapatkan dari data geologi dan kurva HVSR (puncak HVSR dan frekuensi). Kurva HVSR dan data subsurface diletakkan dalam satu folder yang kemudian akan dipanggil dalam proses pembuatan file project untuk inversi.

\section{Ukuran Gambar dan Tabel}

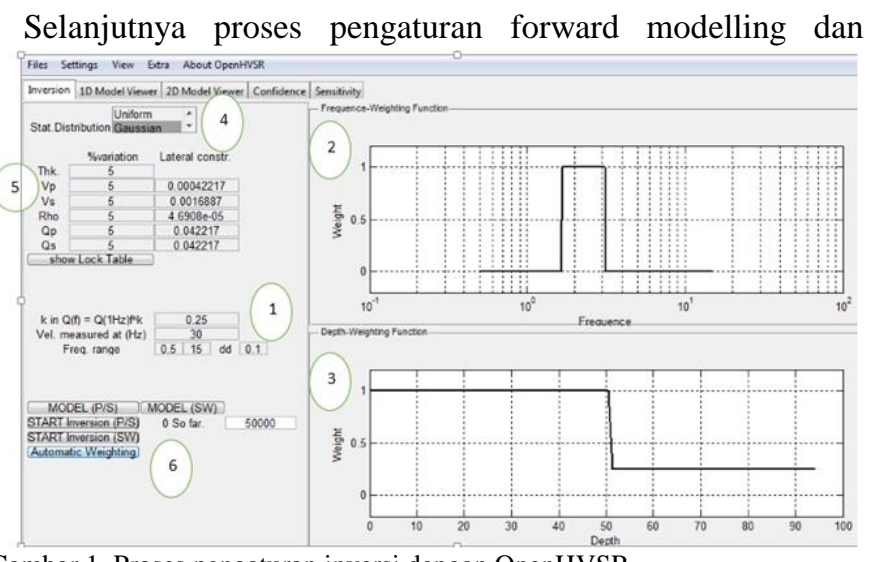

Gambar 1. Proses pengaturan inversi dengan OpenHVSR

inversi (Gambar 1) dapat dijelaskan sebagai berikut. (1) Berisi parameter pengontrol selama proses pemodelan kedepan (FWD), yang juga digunakan dalam proses inversi. Pada kasus ini, faktor atenuasi (Qp, Qs) sangat bergantung terhadap nilai frekuensi dan dapat dirumuskan :

$$
Q=Q_{0} f^{k}
$$

Dengan Q0 adalah faktor atenuasi pada frekuensi $1 \mathrm{~Hz}$ dan untuk nilai $\mathrm{k}$ dianggap konstan yang diasumsikan sama untuk semua lokasi pengukuran. Sedangkan range frekuensi disesuaikan dengan input kurva HVSR yang diambil pada saat pengolahan di geopsy (pada penelitian ini $0.5 \mathrm{~Hz}-15 \mathrm{~Hz}$ ). Setelah parameter pemodelan kedepan diatur selanjutnya yaitu parameter pengontrol inversi. Pada gambar 1 pada pengaturan (2) menunjukkan bahwa fungsi pembobotan yaitu yang menjadi fokusan selama proses inversi sesuai dengan hasil pengolahan kurva HVSR. Hal ini dpat dilakukan dengan mengklik kanan pada jendela tersebut lalu lakukan "modify weighrhing function" hal tersebut juga dilkukan pada tab (3), namun pada tab (3) merupakan fungsi pembobotan terhadap kedalaman. Sedangkan untuk statistik distribusi sebarannya dapat dipilih distribusi uniform atau gaussian (4). Pada penelitian digunakan distribusi probabilitas Gaussian (distribusi normal) karena distribusi ini paling sering digunakan dalam analisis statistik.

Sedangkan pada tab (5) digunakan untuk mengatur 
persentase perubahan maksimum pada setiap parameter terhadapa parameter lainnya. Untuk memulai inveri dapat dilakukan pada pengaturan (6). Pada pengaturan nomor (1) samapai (6) sangat berpengaruh terhadap semua tabs (model 1D dan 2D) termasuk sensitivitasnya.

\section{PEMBAHASAN}

\section{A. Analisis Frekuensi Dominan Kurva HVSR}

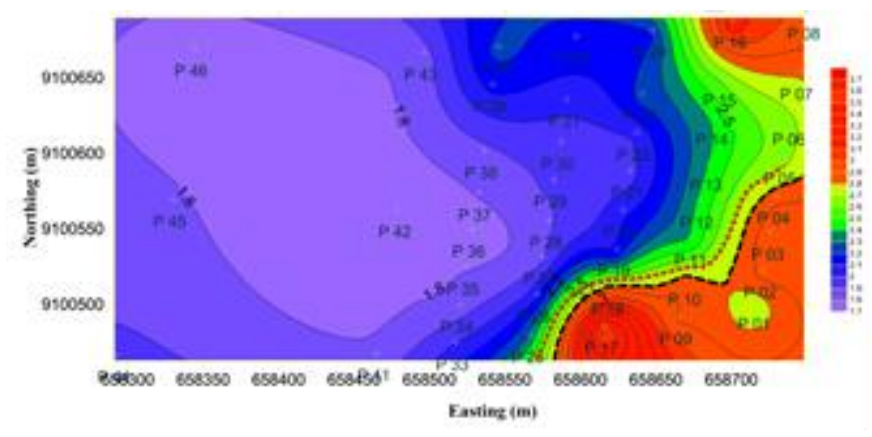

Gambar 2. Peta persebaran frekuensi natural

Hasil analis dari kurva HVSR adalah frekuensi natural dan puncak HVSR yang mencerminkan karakteristik dinamik di daerah setempat. Pada penelitian ini rentang nilai frekuensi natural yang di dapatkan bervariasi yaitu berkisar $1.77 \mathrm{~Hz}$ $3.63 \mathrm{~Hz}$. Pada gambar 2 merupakan kontur dari persebaran nilai frekuensi natural pada daerah penelitian dimana nilainya relatif seragam, namun pada daerah yang telah mengalami longsor memiliki respon perbedaan yang sangat signifikan dari daerah sekitarnya. Hal ini disebakan karena lapisan lunak yang tebal sudah tergerus sehingga menyebabkan lapisan bedrock lebih dekat dengan permukaan. Berdasarkan observasi dilapangan lapisan tanah yang tergerus memiliki ketebalan lebih dari 20 meter. Berdasarkan gambar tersebut garis kontur yang berwarna hitam putus-putus merupakan area yang telah mengalami longsor dan lapisan tanahnya telah tergerus habis oleh hujan. Yaitu terletak pada titik pengukuran P-01, P-02, P03, P-04, P-05, P-09, P-10, P-17, dan P-18 dengan respon frekuensi 2.9-3.7 Hz. Pada titik pengukuran P-08 dan P-16 juga memiliki respon frekuensi yang cukup tinggi yaitu sama dengan daerah yang telah mengalami amblesan atau gerusan. Hal ini sesuai dengan kondisi geologi setempat yang memiliki elevasi yang rendah sehingga asosiasi dengan lapisan bedrock lebih dangkal dengan asumsi deliniasi batas geologi bawah permukaan datar (flat). Dimana frekuensi natural erat hubungannya dengan kedalaman bedrock, keduanya memiliki hubungan berbanding terbalik, artinya nilai frekuensi yang rendah berasosiasi dengan kedalaman bedrock yang dalam [4]. Jadi berdasarkan analisis frekuensi natural dapat diprediksi bahwa lapisan sedimen lunak semakin tebal kearah barat. Namun, berdasarkan penelitian Sungkono (2011) frekuensi natural tidak hanya dipengaruhi oleh kedalaman bedrock (ketebalan sedimen) tapi juga dikontrol oleh kecepatan gelombang geser [5].

Sedangkan garis kontur putus-putus yang berwarna merah pada gambar 2 diatas merupakan batas area yang mengalami landslide yaitu pada titik pengukuran P-25, P-19, P-11, P-06 dan P-07. Pada titik tersebut berdasarkan observasi dilapangan dan data topografi terletak pada slope yang miring, sehingga area ini diprediksi merupakan titik yang paling rawan terhadap longsor (landslide) susulan jika terjadi hujan terus-menerus. Meskipun berdasarkan nilai frekuensi pada titik tersebut memiliki nilai yang lebih besar dibandingkan dengan titik pengukuran pada kontur yang berwarna biru (1.7-2.4 Hz). Namun pada titik pengukuran pada kontur yang berwarna biru memiliki efek kerusakan terhadap bangunan yang paling parah apabila terjadi getaran atau gempa bumi.

\section{B. Analisis Puncak HVSR}

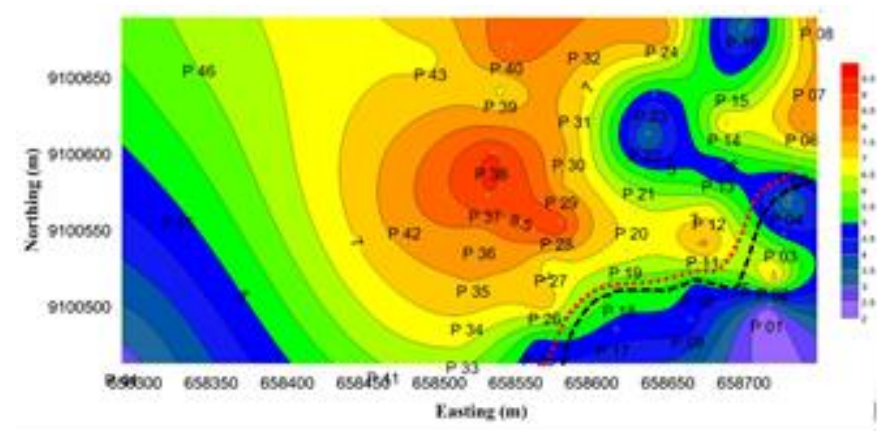

Gambar 3. Peta persebaran puncak HVSR

Nilai Puncak HVSR berhubungan dengan perbandingan antara kontras impedansi lapisan permukaan dengan lapisan dibawahnya. Perubahan nilai puncak HVSR suatu daerah disebabkan karena perubahan sifat fisik batuan seperti terjadinya pelapukan. "Ref. [6]" menyatakan pada batuan yang sama, nilai puncak HVSR dapat bervariasi sesuai dengan tingkat deformasi dan pelapukan pada tubuh batuan tersebut. Sedangkan menurut "Ref. [5]" puncak kurva HVSR dipengaruhi oleh Vs, densitas, Vp, dan Qs sehingga dapat diketahui bahwa daerah yang rawan kerusakan bangunan akibat getaran tanah ialah daerah yang permukaannya tersusun atas sedimen lunak (gambut, pasir, pasir lanauan) dengan bedrock yang keras. Karena pada geologi yang seperti ini, kontras impedansinya besar. Pada penelitian ini didapatkan nilai puncak HVSR berkisar dari 2 sampai 9 (Gambar 3).

Deareah penelitian berdasarkan peta geologi tersusun pasir dan pasir lanauan. Serta berdasarkan observasi dilapangan menunjukkan bahwa area penelitian pada lapisan sedimen permukaan sudah mengalami pelapukan. Sehingga hal ini menyebabkan pada daerah penelitian didominasi oleh nilai puncak HVSR yang tinggi. Menurut Nakamura (2000) parameter puncak HVSR yang dapat merusak bangunan adalah berkisar antara > 3 dan berasosiasi dengan frekuensi rendah [4]. Berdasarkan pernyataan tersebut maka dapat disimpulkan bahwa di daerah penelitian dapat dikategorikan sebagai daerah yang rawan apabila ada getaran gempa bumi karena dominasi nilai frekuensi dan puncak HVSR-nya. Namun, kerusakan yang paling besar apabila terjadi gempa bumi yaitu terletak pada titik pengukuran P-28, P-29, P-36, P-37, P-38 dan P-42. Nilai puncak HVSR diatas 3 tersebar di seluruh area penelitian kecuali titik pengukuran P-01 dan P-44 yang memiliki nilai 
puncak HVSR dibawah 3. Berdasarkan sebaran nilai puncak HVSR tersebut perbedaan topografi bukanlah salah satu faktor yang mempengaruhi nilai dari puncak HVSR.

\section{Analisis Indeks Kerentanan Tanah}

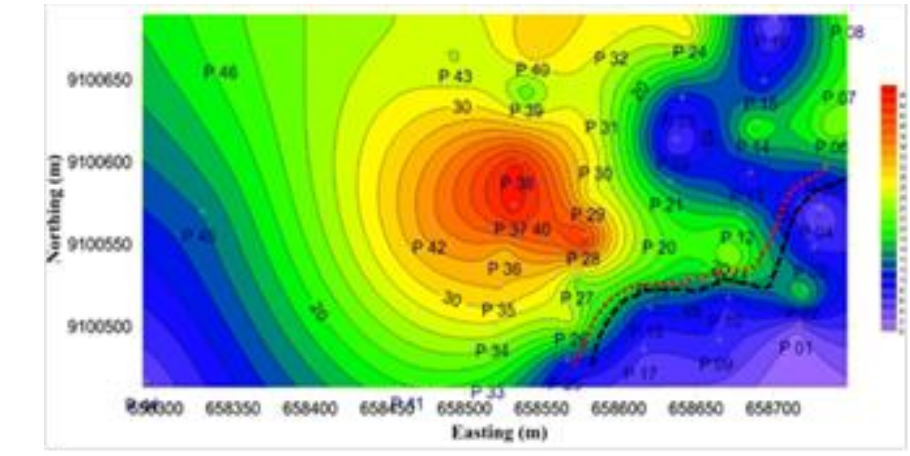

Gambar 4. Peta persebaran indeks kerentanan tanah

Pada gambar 4 merupakan peta persebaran indeks kerentanan tanah pada daerah penelitian. Nilai indeks kerentanan tanah pada daerah penelitian yaitu berada pada rentang 1.5 - 44.7. Apabila dikorelasikan dengan indeks kerentanan di daerah Graben Bantul. Daerah yang mengalami kerusakan parah akibat gempa bumi Bantul 2006 yaitu terjadi pada daerah yang memiliki nilai indeks kerentanan tanah diatas 10 [7]. Daerah penelitian mayoritas memiliki nilai indeks kerentanan tanah diatas 10 yang tersebar diseluruh area titik pengukuran mikrotremor. Hanya dibeberapa titik pengukuran saja yang memiliki nilai indeks kerentanan tanah di bawah 10 , terutama pada daerah yang sudah tergerus oleh hujan hingga ketebalan lebih dari 20 meter. Hal ini menunjukkan bahwa pada titik ini lebih dekat dengan lapisan bedrock dan menjadi titik yang paling aman dari bahaya seismisitas apabila didirikan suatu bangunan.

Apabila ditinjau dari sebaran nilai indeks kerentanan tersebut daerah penelitian menunjukkan sangat rentan terhadap efek lokal yang diakibatkan oleh gempa bumi. Hal ini disebabkan karena secara umum sebaran nilai indeks kerentanan tanahnya sangat tinggi. Terutama pada daerah yang memiliki lereng yang miring seperti pada titik pengukuran P25, P-26, P-19, dan P-11 berdasarkan nilai kerentanan dan kelerengannya diprediksi akan terjadi longsor susulan jika tidak dilakukan mitigasi. Berdasarkan analisa tersebut juga ditemukan titik potensi longsor baru yang mungkin akan terjadi. Yaitu terletak pada titik pengukuran P-06, P-07 dan P08. Karena berdasarkan observasi dilapangan pada titik pengukuran tersebut berada pada kelerengan yang curam dan berdasarkan analisis mikrotremor mimilki nilai indeks kerentanan tanah lebih dari 10. Namun, Pada P-37, P-38 dan P-40 memiliki kerusakan paling parah jika didirikan bangunan akibat gempa bumi. Hal tersebut sesuai berdasarkan analisis frekuensi dan amplifikasi HVSR diatas.

\section{Persebaran Kecepatan Gelombang Geser (Vs)}

Estimasi persebaran kecepatan gelombang geser dari 46 kurva HVSR (reliable) telah dilakukan dengan software OpenHVSR pada penelitian ini. Seperti yang telah dijelaskan sebelumnya bahwa hasil kurva HVSR dari pengukuran mikrotremor dipengaruhi oleh kondisi geologi setempat. Sedangkan kondisi geologi pada daerah penelitian beragam, terutama dilihat dari kenampakan permukan yang memiliki perbedaan elevasi yang signifikan. Seluruh kurva HVSR hasil pengolahan mikrotremor yang telah diinversikan dengan data geologi kemudian dilakukan profiling persebaran kecepatan gelombang geser (Vs) seperti yang disajikan dalam gambar 5 . Dilakukannya profiling ini adalah untuk memudahkan dalam proses interpretasi. Profil sayatan ini mengarah sesuai desain akuisisi yaitu dari selatan ke utara sebanyak 7 sayatan.

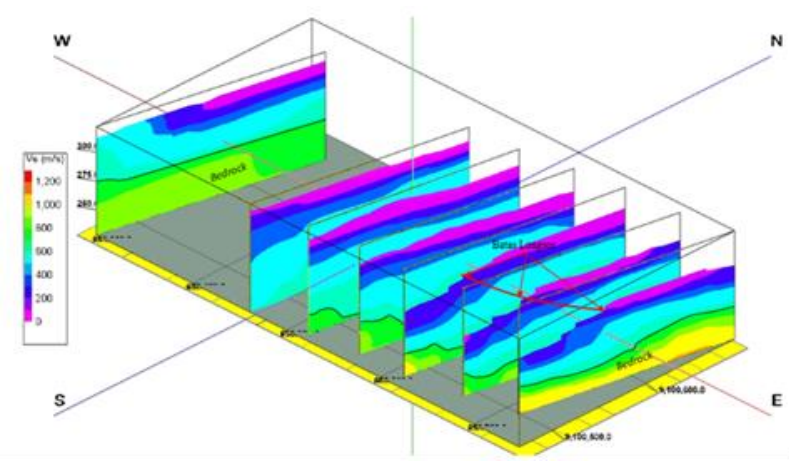

Gambar 5. Profil sebaran kecepatan gelombang geser di daerah penelitian

Berdasarkan profil tersebut didapatkan nilai kecepatan geser 750-1200 m/s mayoritas pada kedalaman 50-60 meter yang tersebar pada daerah penelitian di setiap sayatan. Kecuali pada sayatan 7 (paling ujung barat) kedalaman bedrock (750-1200 $\mathrm{m} / \mathrm{s}$ ) di dapatkan pada kedalaman 37-40 meter. Menurut "Ref. [8]" klasifikasi tanah permukaan berdasarkan pada SNI 17262012 yang sesuai dengan rentang nilai kecepatan geser yang dihasilkan pada penelitian ini, tergolong pada klasifikasi B, C, D dan E. Dengan klasifikasi B sudah termasuk batuan (750 $\mathrm{m} / \mathrm{s}<\mathrm{Vs} \leq 1500 \mathrm{~m} / \mathrm{s}$ ), C merupakan tanah sangat padat dan batuan lunak $(350 \mathrm{~m} / \mathrm{s} \quad<\mathrm{Vs} \leq 750 \mathrm{~m} / \mathrm{s})$, klasifikasi D merupakan tanah sedang $(175 \mathrm{~m} / \mathrm{s}<\mathrm{Vs} \leq 350 \mathrm{~m} / \mathrm{s})$, dan klasifikasi $\mathrm{E}$ tanah lunak dengan nilai kecepatan geser kurang dari $175 \mathrm{~m} / \mathrm{s}$. Berdasarkan klasifikasi SNI tersebut tanah lunak tersebar pada seluruh area penelitian dengan kedalaman 8-15 meter yang ditandai dengan warna ungu. Tanah lunak dengan ketebalan 8-15 meter ini menjadi pemicu terjadinya longsororan apabila terletak pada lereng yang curam dan dibidangi oleh tanah yang lebih padat.

Tiga sayatan dari timur pada gambar 4.15 merupakan daerah yang telah terjadi longsor lebih jelasnya dapat dilihat pada gambar 4.16, dengan arah longsoran keselatan. Sehingga pada ujung selatan dari sayatan tersebut lapisan lunaknya lebih sedikit/bahkan tidak kelihatan lapisan lunak bila dibandingkan dengan sayatan lainnya. Hal ini dikarenakan lapisan lunak tersebut sudah hilang tererosi oleh hujan. Sedangkan garis putus-putus berwarna merah di duga sebagai bidang gelincir dari longsor tersebut dengan nilai kecepatan geser 200-300 m/s yang diklasifikasikan sebagai tanah tipe D berdasarkan SNI 1726-2012. Berdasarkan penampang tersebut longsor susulan kemungkinan akan terjadi lagi bila terjadi hujan secara terus 
menerus. Hal tersebut dikarenakan masih tebalnya tanah lunak yang terletak pada bidang miring. Berdasarkan gambar 6 lapisan lunak yang berada pada lereng longsor/batas longsoran memiliki ketebalan 8 meter. Jadi tanah yang hilang tergerus hujan memiliki ketebalan sekitar 25 meter. Hal ini sesuai pada saat observasi dilapangan, bahwa tanah yang hilang diperkirakan sekitar lebih dari 20 meter. Hasil ini juga membuktikan bahwa metode mikrotremor mampu untuk mengkarakterisasi longsoran dalam mendeliniasi batas-batas bidang longsoran tersebut.

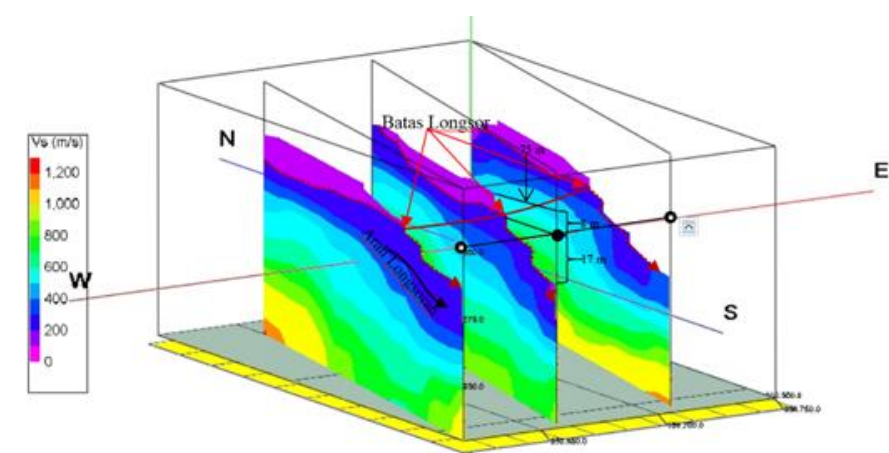

Gambar 6. Profil sebaran kecepatan gelombang geser di daerah penelitian.

\section{KESIMPULAN}

Pengukuran mikrotremor dengan metode HVSR dan analisis kecepatan gelombang geser dari hasil kurva HVSR mikrotremor di desa Olak Alen Blitar telah menghasilkan karakteristik dinamik tanah daerah setempat serta dari hasil profil kecepatan gelomabng geser lapisan keras di daerah penelitian (bedrock) berada pada kedalaman 50-60 m dengan Vs $750-1200 \mathrm{~m} / \mathrm{s}$.

Selanjutnya setelah diketahui karakteristik dinamik dan profil tanah di daerah penelitian, pendirian bangunan dilokasi penelitian disarankan mengikuti international building code untuk mengurangi resiko akibat gempa bumi.

\section{UCAPAN TERIMA KASIH}

Penulis mengucapkan terima kasih kepada Direktorat Pendidikan Tinggi, Departemen Pendidikan dan Kebudayaan Republik Indonesia yang telah memberikan dukungan finansial melalui Beasiswa Bidik Misi tahun 2013-2017'. Penulis juga di menyampaikan ucapan terima kasih kepada. Novritza, Dwipa, Alif, Jubel dan Nomensen yang telah membantu dalam pengambilan data penelitian ini.

\section{DAFTAR PUSTAKA}

"tanggapan-bencana-gerakan-tanah-kecamatan-selorejo-kabupatenblitar-provinsi-jawa-timur," Pusat Vulkanologi dan Mitigasi Bencana Geologi, 2016. [Online]. Available: http://pvmbg.geologi.esdm.go.id/index.php/gerakan-tanah/kejadiangerakan-tanah/1379-tanggapan-bencana-gerakan-tanah-kecamatanselorejo-kabupaten-blitar-provinsi-jawa-timur.

[2] M. Sjarifudin and S. Hamidi, Peta geologi lembar Blitar, Jawa. Bandung: Pusat Penelitian dan Pengembangan Geologi, 1992.

[3] A. R. and S. D. Y. Nakamura, Gurler, E. Dilek, J. Saita, "Vunerability Investigation of Roman Colosseum Using Microtremor," 12WCEE, 2000.

[4] W. T. Sutrisno, "Profilling persebaran kecepatan gelombang geser (Vs) menggunakan inversi mikrotremor spectrum Horizontal -toVertical Spectral Ratio (HVSR)," Institut Teknologi Sepuluh Nopember, 2014

[5] L. G. and A. G. G. Gardner, "Formation velocity and density -the diagnostic basic for stratigraphic traps," Geophys. 39, pp. 770-780, 1974.

[6] S. B.J. Santosa, "KARAKTERISASI KURVA HORIZONTAL-TOVERTICAL SPECTRAL RATIO: KAJIAN LITERATUR DAN PERMODELAN," J. NEUTRINO, Mar. 2012.

[7] M. and R. S. B. S. Mulyatno, Penentuan Zona Rawan Guncangan Bencana Gempa Bumi Berdasarkan Analisis Amplifikasi HVSR Mikrotremor dan Analisis Periode Dominan Daerah Liwa dan Sekitarnya. Geofisika Eksplorasi, 2013. 